\title{
POLA KOMUNIKASI KELUARGA DALAM PERSPEKTIF ISLAM
}

\section{Samsinar S.}

\begin{abstract}
Abstrak : Komunikasi keluarga merupakan hal terpenting yang harus dimaksimalkan dalam menjaga keutuhan keluarga. Komunikasi ini bisa dilakukan melalui komunikasi antara suami dengan istri, komunikasi antara orangtua dengan anak, dan komunikasi antarsaudara. Pola komunikasinya dapat dilakukan dengan cara yang demokratis melalui musyawarah dan mufakat. Islam sangat menjunjung tinggi prinsip ini, sehingga berbagai masalah yang dihadapi harus diselesaikan dengan musyawarah dan mufakat, termasuk dalam menyelesaikan konflik yang terjadi dalam keluarga. Dengan prinsip dan pola ini, maka keluarga akan harmonis dan bahagia.
\end{abstract}

Kata Kunci : Komunikasi, keluarga, Islam

Abstract: Family of communication is the most important thing that must be maximized in maintaining family integrity. This communication can be done through communication between husband and wife, communication between parents and children, and communication between siblings. The pattern of communication can be done in a democratic manner through deliberation and consensus. Islamic highly upholds this principle, so that the various problems encountered must be resolved by deliberation and consensus, including in resolving conflicts that occur in the family. With these principles and patterns, the family will be harmonious and happy.

Kata Kunci : communication, family, Islamic

\section{PENDAHULUAN}

Keluarga merupakan unit terkecil dalam masyarakat yang terdiri atas suamiistri atau suami-istri dan anaknya, atau ayah dan anaknya, atau ibu dan anaknya, atau keluarga sedarah dalam garis lurus ke atas, atau ke bawah sampai dengan derajat ketiga. ${ }^{1}$ Kehidupan keluarga sebagai kelompok sosial hidup secara berkelompok, tidak menyendiri, akan tetapi berada dalam kehidupan sosial dengan budanyanya untuk memenuhi kebutuhan jasmani dan rohani serta memberikan kesempatan untuk bersosialisasi dengan para anggota dalam keluarga termasuk anak-anaknya. ${ }^{2}$ Dalam bersosialisasi dan berinteraksi atau berkomunikasi dengan lainnya harus dilandasi dengan prinsip kejujuran, kepercayaan, kesetiaan sehingga keluarga tidak rapuh dan tetap kokoh walaupun terjadi goncangan dalam kehidupan, akan tetapi bisa dilalui dan diatasi dengan baik.

Setiap keluarga memiliki problem tersendiri. Begitu banyak problem yang dialami dalam keluarga baik problem anak, perselingkuhan, dan perceraian, dimulai dengan kurangnya komunikasi yang baik dalam keluarga. Keluarga seperti

\footnotetext{
${ }^{1}$ Undang-Undang No. 23 Tahun 2002 tentang Perlindungan Anak, Bab I Pasal 1 (Jakarta: Indonesia Legal Center Publishing, 2003), h. 3.

${ }^{2}$ Moehammad Isa Soelaeman, Pendidikan dalam Keluarga (Bandung: Alfabeta, 1994), h. 21.
} 
bangunan yang harus berdiri kokoh, pondasinya harus kuat, tidak boleh rapuh, jika ada problem harus segera diselesaikan melalui komunikasi, karena problem yang dihadapi dalam keluarga berpangkal pada terhambatnya proses dan saluran komunikasi. Proses komunikasi dapat berjalan dengan baik kalau dalam keluarga saling memahami dan saling membuka diri untuk bisa menyelesaikan berbagai problem. Pemahaman bersama diperlukan dalam keluarga, agar keluarga tetap harmonis. Sedangkan keterbukaan diperlukan agar masalah terselesaikan dengan mengungkapkan informasi yang biasanya disembunyikan. Dengan demikian, komunikasi dalam keluarga sangat penting demi menjaga hubungan baik dalam keluarga.

Komunikasi dalam keluarga harus lebih intens dan sesering mungkin. Orangtua harus mengajak anak untuk selalu berkomunikasi, begitu juga sebaliknya. Cukup banyak masalah yang timbul karena kurangnya atau tidak adanya komunikasi yang baik dalam keluarga. Hal ini harus disadari, khususnya dari pihak orangtua. Terjadinya interaksi dan komunikasi dalam keluarga akan saling mempengaruhi satu sama lain dan saling memberikan stumulus dan respon. Dengan interaksi antara orangtua dan anak, akan membentuk gambaran-gambaran tertentu pada masingmasing pihak sebagai hasil dari komunikasi. Anak akan mempunyai gambaran tertentu mengenai orantuanya. Dengan adanya gambaran tersebut sebagai hasil persepsinya melalui komunikasi, maka akan terbentuk sikap-sikap tertentu dari masing-masing pihak. Bagi orangtua, anak sebagai objek sikap, dan sebaliknya bagi anak, orangtua sebagai objek sikap. Pada diri anak akan terbentuk sikap tertentu terhadap orangtuanya, begitu pun sebaliknya, pada orangtua akan terbentuk sikap tertentu terhadap anaknya.

Anak memiliki sikap yang berbeda dengan orangtuanya. Ada anak yang menganggap orangtuanya adalah segalanya, ada juga yang menganggap orangtuanya sadis, kejam, kikir, judes, dan tidak mau menuruti keinginan anaknya. Anak yang menganggap orangtuanya segalanya, akan mencontoh dan meneladani orangtuanya. Sebaliknya, anak yang menganggap orangtuanya sadis dan seterusnya, maka ia akan menghindar dan menarik diri dari orangtuanya, sehingga memilih idola diluar dari orangtuanya. Dengan demikian, sikap yang dimiliki anak merupakan proses interaksi dan komunikasi yang terjadi dalam keluarga. Oleh karena itu, interaksi dan komunikasi yang baik dalam keluarga memberikan dampak positif bagi tumbuh kembangnya anak.

Dalam berkomunikasi antara orangtua dan anak harus memiliki pola komunikasi yang lebih baik. Pola menyakut pesan yang terkait dengan situasi dan kondisi yang mengacu pada sesuatu yang membungkus inti pesan itu. Pola juga memberikan data untuk memahami dan mengerti tindakan dan tingkah laku baik secara individu maupun secara kelompok atau secara organisasi. Pola komunikasi menunjukkan suatu identifikasi untuk mengakses tingkah laku komunikasi dalam suatu sistem, karena pola komunikasi menyediakan konteks atau ruang untuk memahami tingkah laku spesifik. Pola komunikasi disesuaikan dengan kondisi anggota dan komunikan yang ada pada saat terjadinya komunikasi dan interaksi dalam lingkungannya.

Ada tiga faktor pembentuk pola komunikasi seseorang yaitu :

\footnotetext{
${ }^{3}$ Ngalimun, Ilmu Komunikasi : Sebuah Pengantar Praktis (Cet. I; Yogyakarta: Pustaka Baru Press, 2017), h. 140.
} 
1. Proses sejarah atau pengalaman masa lalu yang kemudian membentuk kebiasaan-kebiasaan yang menjadi bagian dari kepribadian

2. Kapasitas diri sebagai akibat dari faktor pendidikan, pelatihan serta pengalaman hidup diri seseorang dalam menempuh kehidupan, dan

3. Maksud dan tujuan dari aktivitas komunikasi sehingga membawa kepada penyesuaian pesan, metode dan media yang digunakan.

Jika pola komunikasi di atas dikaitkan dengan pola komunikasi keluarga, maka orangtua harus memberikan pembiasaan yang baik agar tertanam dan terbentuk kepribadiaan dengan baik, memberikan pendidikan baik di lingkungan keluarga, sekolah dan masyarakat, dan melakukan aktivitas komunikasi yang baik antara orangtua dan anak, agar tidak terjadi hal-hal yang tidak diharapkan. Oleh karena itu, hubungan antara orangtua dan anak harus terjalin dengan baik dengan menggunakan pola-pola tertentu, ada tiga pola hubungan orangtua dan anak yang akan menimbulkan efek yang sangat penting bagi pertumbuhan dan perkembangan anak. Ketiga pola hubungan tersebut yaitu :

1. Keluarga yang demokratis

Dalam keluarga ini, anak akan mudah bergaul, berinteraksi dengan yang lain, aktif dan ramah dengan orang lain. Anak tidak tertutup dan membuka diri terhadap kebenaran-kebenaran yang datang dari luar dirinya. Anak juga akan berani berpendapat dan senang berdiskusi atau mengutamakan musyawarah dan mufakat sebelum memutuskan sesuatu

2. Keluarga yang apatis

Anak yang dibesarkan dalam keluarga seperti ini, tidak aktif atau bahkan sering menarik diri dari kehidupan sosial. Perkembangan fisik anak yang dibesarkan dalam keluarga seperti ini cenderung terhambat. Anak sering frustasi dan dapat menyebabkan mudah membenci dan mencurigai orang lain. Hal ini terjadi karena tidak mendapatkan interaksi yang baik di dalam keluarga.

3. Keluarga yang otoriter

Pola hubungan ini, anak yang dibesarkan dalam keluarga yang otoriter biasanya tidak berani melawan, tidak agresif, dan selalu tergantung pada orang lain atau orangtuanya. Anak yang didik dengan pola ini memiliki kreativitas yang minim, daya fantasi yang kurang, sehingga mengurangi kemampuan anak untuk berpikir abstrak. ${ }^{5}$

Berdasarkan ketiga pola di atas, maka pertumbuhan dan perkembangan anak tergantung pada pola yang diterapkan orangtua. Orangtua tinggal memilih yang mana yang terbaik buat anaknya. Pola di atas dihubungkan dengan pola komunikasi keluarga, maka orangtua yang baik yaitu orangtua yang selalu menjaga komunikasi dengan baik, saling percaya, jujur, saling membuka diri atau mengungkapkan masalah-masalah yang dialami. Agar pola ini terwujud maka pola hubungan keluarga demokratis hendaklah menjadi pilihan bagi orangtua dan anak sehingga keluarga menjadi harmonis dan bahagia.

\footnotetext{
${ }^{4}$ Bambang S. Ma'arif, Komunikasi Dakwah : Paradigma Untuk Aksi (Cet. I; Bandung: Simbiosa Rekatama Media, 2010), h. 79.

${ }^{5}$ Nur Solikin, Rumahku Madrasahku: Jadikan Rumah sebagai Pusat Inspirasi Anak (Cet. I; Yogyakarta: Laksana, 2018), h. 112-113.
} 


\section{PEMBAHASAN}

\section{Keluarga dalam Perspektif Al-Qur'an}

Dalam al-Qur'an, kata keluarga dipresentasikan melalui kata ahl. Di dalam alQur'an, kata ahl diulang sebanyak 128 kali, dan sesuai dengan konteksnya, katakata tersebut tidak selamanya menunjukkan pada arti keluarga, melainkan memiliki arti yang beraga. Pada Q.S. al-A'raf/7:96, kata ahl diartikan penduduk suatu negeri. Begitu juga dalam Q.S. al-Baqarah/1:109, kata ahl berarti penganut suatu ajaran seperti ahl al-kitab. Selain itu, pada Q.S. an-Nisa/4:58, kata ahl ini diartikan sebagai orang yang berhak menerima sesuatu. Selebihnya, kata ahl dalam al-Qur'an ditujukan kepada keluarga dalam arti kumpulan laki-laki dan perempuan yang diikat oleh tali pernikahan dan di dalamnya terdapat orang yang menjadi tanggungannya, seperti anak dan mertua. ${ }^{6}$

Ada beberapa unsur pokok yang terkandung dalam pengertian keluarga yaitu :

1. Keluarga sering kali dimulai dengan perkawinan atau penetapan pertalian kekeluargaan

2. Keluarga berada dalam batas-batas persetujuan kekeluargaan

3. Anggota keluarga dipersatukan oleh pertalian perkawinan, darah, dan adopsi sesuai dengan hukum dan adat istiadat yang berlaku

4. Anggota keluarga secara khas hidup secara bersama pada suatu tempat tinggal yang sama

5. Interaksi dalam keluarga berpola pada norma-norma, peranan-peranan, dan posisi-posisi status yang ditetapkan oleh masyarakat

6. Dalam keluarga terjadi proses reproduksi dan edukasi ${ }^{7}$

Keluarga sangat penting bagi pertumbuhan dan perkembangan anak. Anak tidak bisa lepas dari peran serta orangtua. Orangtua berperan penting memelihara, melindungi, dan memperhatikan serta mendidik anaknya. Tanpa perlindungan, pengawasan, bimbingan, dan perhatian orangtua, maka anak tidak bisa tumbuh dan berkembang secara maksimal.

Salah satu hubungan yang sangat erat dan tidak bisa dipisahkan adalah hubungan keluarga. Jika terjadi perubahan budaya dan sosial kemasyarakatan, maka hubungan keluarga tidak dapat terlupakan. Keluarga mempunyai arti penting bagi anak, karena dari keluargalah, anak akan mendapatkan segalanya, dan satu hal yang terpenting adalah pembinaan dan pendidikan mental.

Pembinaan dan pendidikan mental bagi anak menjadi tugas keluarga. Keluarga berperan sebagai pelindung dan pendidik anggota keluarganya, sebagai penghubung dalam masyarakat, sebagai pencukup kebutuhan-kebutuhan ekonominya, sebagai pembina kehidupan religiusnya, sebagai penyelenggara rekreasi keluarga dan pencipta suasana yang aman dan nyaman bagi seluruh anggota keluarga dan khusus

${ }^{6}$ Muhammad Fuad al-Baqy, al-Mu'jam al-Mufahras li Alfazh al-Qur'an al-Karim (Beirut: Dar al-Fikr, 1987), h. 28.

${ }^{7}$ Nur Solikin, Rumahku Madrasahku: Jadikan Rumah sebagai Pusat Inspirasi Anak, h. 74. 
bagi suami-istri, sebagai tempat memenuhi kebutuhan biologisnya. ${ }^{8}$ Selain memiliki peranan, juga memiliki fungsi yaitu fungsi edukasi, proteksi, afeksi, sosialisasi, reproduksi, religi, ekonomi, rekreasi, biologis, dan transformasi. ${ }^{9}$

Fungsi edukasi dalam keluarga adalah fungsi yang berkaitan dengan pendidikan anak dan pendidikan anggota keluarga. Orangtua adalah pendidik pertama dan utama. Disebut sebagai pendidik pertama, karena orangtualah yang pertama mendidik anaknya, disebut utama karena orangtua sangat berpengaruh terhadap tumbuh kembang anak. Sebagai contoh, yang dilakukan oleh Nabi Yakub terhadap keluarganya ketika telah datang tanda-tanda kematian kepadanya. Dalam Q.S. alBaqarah/2:133, Allah swt., berfirman :

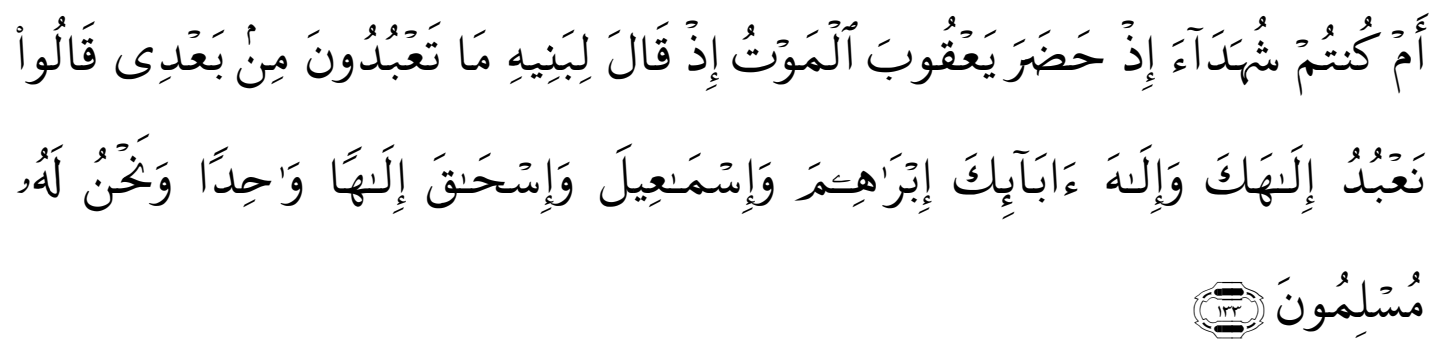

Terjemahnya :

Adakah kamu hadir ketika Ya'qub kedatangan (tanda-tanda) maut, ketika ia berkata kepada anak-anaknya: "Apa yang kamu sembah sepeninggalku?" mereka menjawab: "Kami akan menyembah Tuhanmu dan Tuhan nenek moyangmu, Ibrahim, Ismail dan Ishaq, (yaitu) Tuhan yang Maha Esa dan kami hanya tunduk patuh kepada-Nya".

Selain fungsi edukasi, fungsi proteksi dalam keluarga yaitu melindungi para anggota keluarga dari hal-hal yang membahayakan mereka, baik di dunia maupun di akhirat. Dalam konteks ini al-Qur'an memberikan tanggungjawab kepada orangtua agar melindungi dirinya dan anggota keluarganya dari api neraka. Sebagaimana dalam Q.S. al-Tahrim/66:7 :

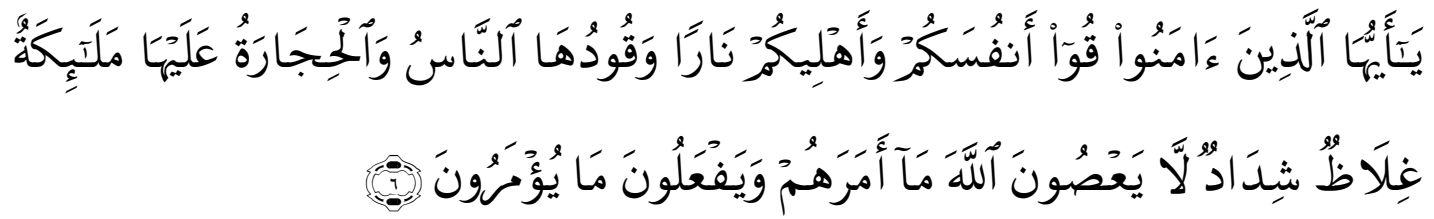

Terjemahnya :

Hai orang-orang yang beriman, peliharalah dirimu dan keluargamu dari api neraka yang bahan bakarnya adalah manusia dan batu; penjaganya malaikatmalaikat yang kasar, keras, dan tidak mendurhakai Allah terhadap apa yang

\footnotetext{
125.

${ }^{8}$ Moehammad Isa Soelaeman, Pendidikan dalam Keluarga (Bandung: Alfabeta, 1994), h.

${ }^{9}$ Nur Solikin, Rumahku Madrasahku: Jadikan Rumah sebagai Pusat Inspirasi Anak, h. 76-

92.
} 
diperintahkan-Nya kepada mereka dan selalu mengerjakan apa yang diperintahkan.

Keluarga juga memiliki fungsi afeksi yaitu memupuk, pencipta kasih sayang, pencipta ketenangan, dan rasa cinta antara sesama anggota keluarga. Fungsi ini tergambar dalam Q.S. al-Rum/30:21 :

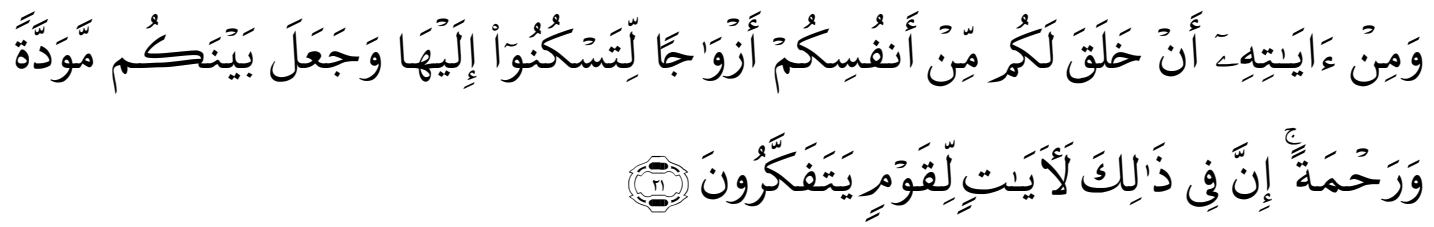

Terjemahnya :

Dan di antara tanda-tanda kekuasaan-Nya ialah Dia menciptakan untukmu isteri-isteri dari jenismu sendiri, supaya kamu cenderung dan merasa tenteram kepadanya, dan dijadikan-Nya diantaramu rasa kasih dan sayang. Sesungguhnya pada yang demikian itu benar-benar terdapat tanda-tanda bagi kaum yang berpikir.

Selain fungsi di atas, fungsi lainnya adalah sosialisasi. Keluarga merupakan lingkungan sosial pertama dan utama. Anak berinteraksi dengan orangtua dan nggota keluarga lainnya. Dalam konteks ini, al-Qur'an menganjurkan agar keluarga menciptakan komunikasi yang harmonis, mengembangkan nilai-nilai kebersamaan dan merumuskan norma sosial yang berlaku bagi semua anggotanya. Sebagaimana termaktub dalam Q.S. al-Nur/24:6 :
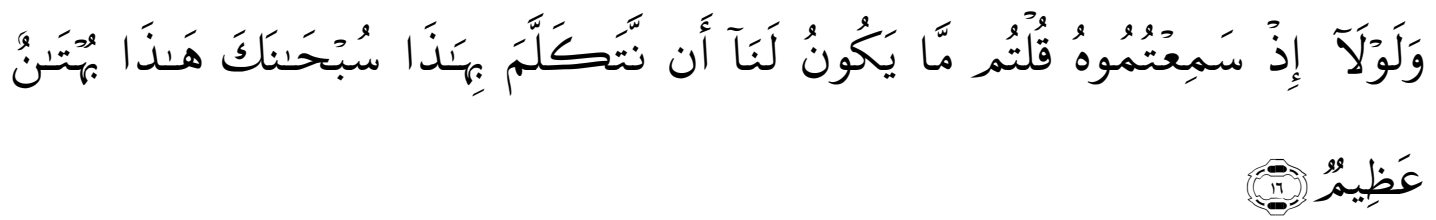

Terjemahnya :

Dan mengapa kamu tidak berkata, diwaktu mendengar berita bohong itu: "Sekalikali tidaklah pantas bagi kita memperkatakan ini, Maha suci Engkau (ya Tuhan kami), ini adalah dusta yang besar."

Selanjutnya, keluarga juga memiliki fungsi reproduksi yaitu untuk melahirkan keturunan sebagai penerus kedua orangtuanya. Sebagaimana dijelaskan dalam Q.S. al-Nisa/4:1 :

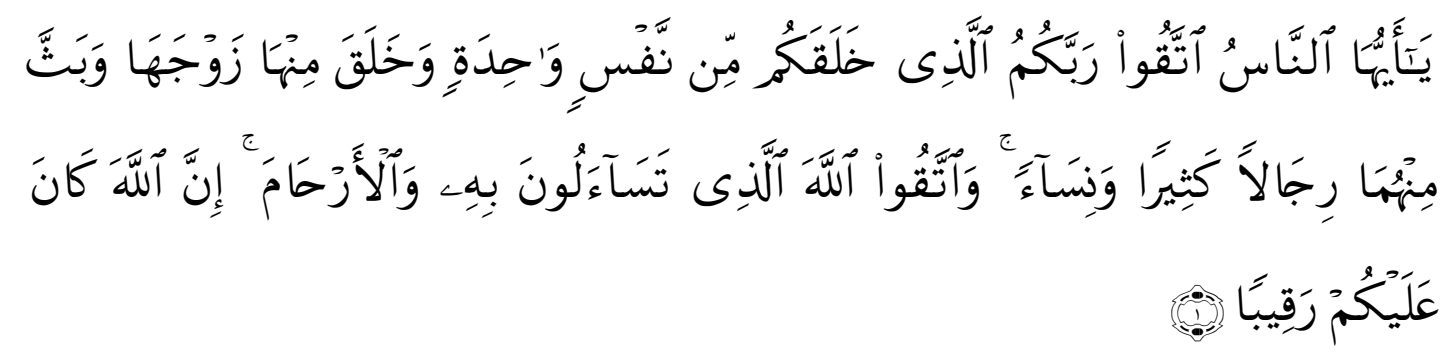

Terjemahnya :

Hai sekalian manusia, bertakwalah kepada Tuhan-mu yang telah menciptakan kamu dari seorang diri, dan dari padanya Allah menciptakan isterinya; dan dari pada keduanya Allah memperkembang biakkan laki-laki dan perempuan yang 
banyak. dan bertakwalah kepada Allah yang dengan (mempergunakan) namaNya kamu saling meminta satu sama lain, dan (peliharalah) hubungan silaturrahim. Sesungguhnya Allah selalu menjaga dan mengawasi kamu.

Keluarga juga memiliki fungsi religi, karena keluarga merupakan sarana utama dalam mendidik, menanamkan pemahaman, dan pengalaman keagamaan. Oleh karena itu, keluarga berperan dalam menciptakan iklim religius bagi anggotanya. Sebagaimana dalam Q.S. Maryam/19:55 :

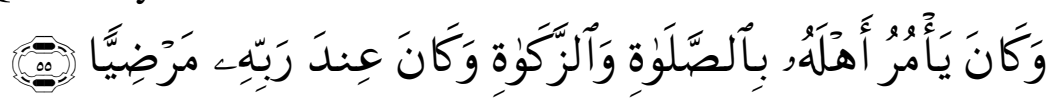

Terjemahnya :

Dan ia menyuruh ahlinya atau umatnya untuk bersembahyang dan menunaikan zakat, dan ia adalah seorang yang diridhai di sisi Tuhannya.

Fungsi lainnya adalah fungsi ekonomi. Dengan terbentuknya keluarga, maka suami bertanggungjawab kepada istri dan anaknya dalam memberikan nafkah bagi kehidupan mereka. Mengenai hal ini terdapat dalam Q.S. al-Nisa/4:34 :

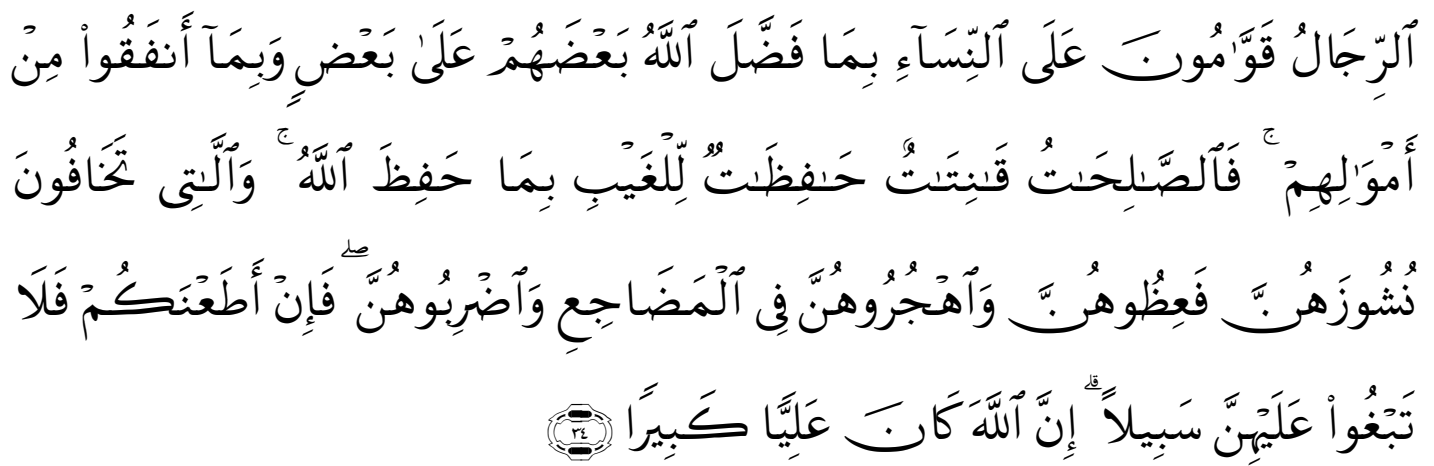

Terjemahnya :

Kaum laki-laki itu adalah pemimpin bagi kaum wanita, oleh karena Allah telah melebihkan sebahagian mereka (laki-laki) atas sebahagian yang lain (wanita), dan karena mereka (laki-laki) telah menafkahkan sebagian dari harta mereka. Sebab itu maka wanita yang saleh, ialah yang taat kepada Allah lagi memelihara diri ketika suaminya tidak ada, oleh karena Allah telah memelihara (mereka). Wanita-wanita yang kamu khawatirkan nusyuznya, maka nasehatilah mereka dan pisahkanlah mereka di tempat tidur mereka, dan pukullah mereka. Kemudian jika mereka mentaatimu, maka janganlah kamu mencari-cari jalan untuk menyusahkannya. Sesungguhnya Allah Maha Tinggi lagi Maha besar.

Selain fungsi ekonomi, keluarga juga memiliki fungsi rekreasi. Fungsi rekreasi berkaitan dengan peran keluarga menjadi lingkungan yang nyaman, hangat, menyenangkan, sebagai tempat menghilangkan rasa letih dan lelah setelah bekerja. Dalam menjalankan fungsi ini, maka keluarga harus menciptakan kekeluargaan dan sikap demokratis agar komunikasi terjalin akrab. Hal ini sejalan dengan kisah Nabi Ibrahim sebagai sosok ayah yang sangat demokratis dan tidak otoriter terhadap anaknya. Sebagaimana termaktub dalam Q.S. al-Shaffat/37:102 : 


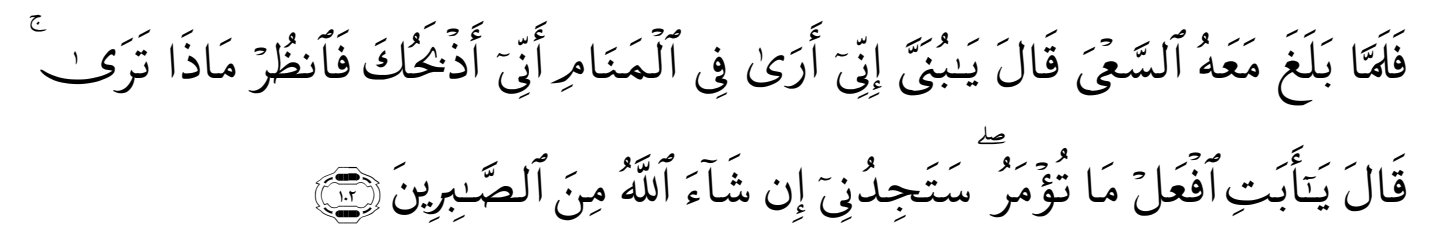

Terjemahnya :

Maka tatkala anak itu sampai (pada umur sanggup) berusaha bersama-sama Ibrahim, Ibrahim berkata: "Hai anakku, sesungguhnya aku melihat dalam mimpi bahwa aku menyembelihmu. Maka pikirkanlah apa pendapatmu!" ia menjawab: "Hai bapakku, kerjakanlah apa yang diperintahkan kepadamu; insya Allah kamu akan mendapatiku termasuk orang-orang yang sabar".

Fungsi lainnya adalah fungsi biologis. Sehubungan dengan fungsi ini, keluarga harus memenuhi kebutuhan biologis anggota keluarganya, seperti perlindungan kesehatan, rasa lapar, kedinginan, kepanasan, kelelahan, kenyamanan, dan kesegaran fisik. Dalam memenuhi kebutuhan biologis ini seperti makan dan minum untuk keluarga harus memenuhi kriteria halal dan bergizi. Untuk hal ini, sesuai dengan Q.S. al-Baqarah/2:168 :

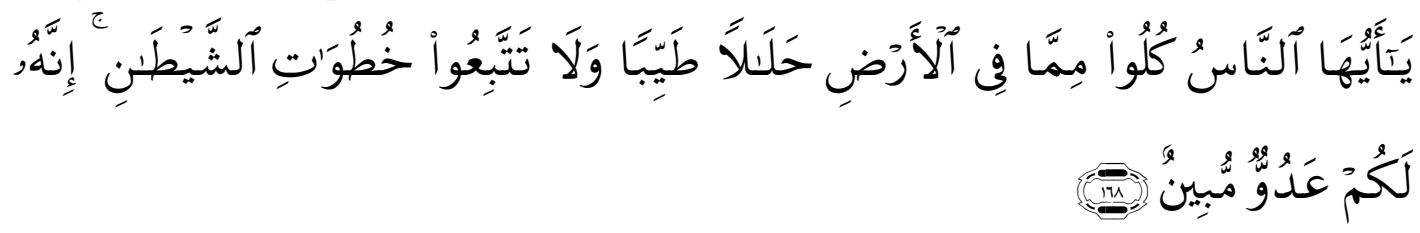

Terjemahnya :

Hai sekalian manusia, makanlah yang halal lagi baik dari apa yang terdapat di bumi, dan janganlah kamu mengikuti langkah-langkah syaitan; karena Sesungguhnya syaitan itu adalah musuh yang nyata bagimu.

Fungsi terakhir adalah transformasi. Fungsi ini berkaitan dengan peran keluarga dalam hal pewarisan tradisi dan budaya bagi anggotanya. Sebagaimana dalam Q.S. al-Zukhruf/43:22 :

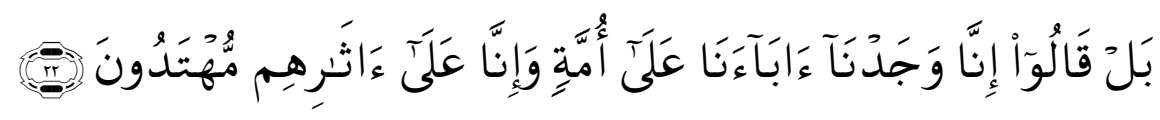

Terjemahnya :

Bahkan mereka berkata: "Sesungguhnya Kami mendapati bapak-bapak kami menganut suatu agama, dan Sesungguhnya kami orang-orang yang mendapat petunjuk dengan (mengikuti) jejak mereka".

Ayat ini menjelaskan bahwa orangtua merupakan pewaris tradisi dan budaya bagi anak-anaknya, dan begitu juga anak-anaknya menjadi pewaris bagi generasi setelahnya.

Dengan sepuluh fungsi di atas, maka keluarga harus menjadi terdepan dan berperan penting dalam memenuhi kebutuhan baik kebutuhan fisik-biologis, maupun sosial-psikologis para anggota keluarganya. Dengan demikian, keluarga akan bahagia dan sejahtera jika para anggota selalu menjaga keutuhan keluarga. 


\section{Bentuk-Bentuk Komunikasi Keluarga}

Keluarga merupakan lingkungan sosialisasi yang pertama bagi anak. Sosialisasi di lingkungan keluarga biasanya disebut sebagai sosialisasi domestik. Dalam sosialisasi ini, secara tidak langsung, anak belajar mengenal jati diri. Oleh karena itu, dalam sosialisasi ini orangtua harus mampu menumbuhkan rasa kekeluargaan kepada anak, karena rasa kekeluargaan akan berdampak positif bagi anak. Keluarga akan menjadi tempat untuk mencurahkan perasaan dan hati anak jika mengalami berbagai masalah. Dengan rasa kekeluargaan inilah, anak akan percaya diri untuk menghadapi hidup yang kuat dan jelas, mendorong dan memotivasi anak untuk menjalankan perintah dan anjuran dari orangtua agar anak selalu berada di jalanNya.

Dalam keluarga terjalin komunikasi baik komunikasi interpersonal dan komunikasi kelompok. Komunikasi yang terjadi antara suami-istri, ayah, ibu dan anak disebut komunikasi interpersonal. Sedangkan komunikasi yang terjadi antara suami-istri, ayah-ibu, anak dan melibatkan orang lain baik saudara, tante, om, kakek, nenek dan keluarga yang lain disebut komunikasi kelompok. Kedua bentuk komunikasi ini tidak dapat dihindari dan terjadi tanpa disadari dalam kehidupan sehari-hari.

Ada dua bentuk dalam komunikasi keluarga yaitu komunikasi interpersonal dan komunikasi kelompok. ${ }^{10}$ Adapun bentuk-bentuk komunikasi keluarga tersebut dapat dijelaskan berikut ini :

1. Komunikasi Interpersonal dalam Keluarga

Komunikasi interpersonal dapat diartikan sebagai komunikasi antarpribadi. Bentuk komunikasi ini, paling sering digunakan oleh anggota keluarga karena membutuhkan komunikasi face to face. Bentuk komunikasi ini, juga dinilai efektif dalam mengubah sikap, pendapat, dan tingkah laku seseorang. Komunikasi interpersonal ini bersifat dialogis, dan langsung ada feed back atau umpan balik dalam komunikasi. Inilah yang menjadi alasan sehingga keluarga lebih banyak menggunakan komunikasi interpersonal. Keluarga akan langsung mengetahui secara pasti efek dari komunikasinya, diterima atau ditolak sehingga komunikasinya bisa dilihat berhasil atau tercapai atau gagal. Jika komunikasinya gagal, maka keluarga akan mencari cara lain dan kesempatan yang lain untuk lebih meyakinkan anaknya agar menerima pesan yang disampaikan.

Ada beberapa fungsi komunikasi interpersonal dalam keluarga yaitu memenuhi kebutuhan psikologis, mengembangkan kesadaran diri, meningkatkan dan menjaga hubungan, menggali informasi, dan memengaruhi. Dalam hal memenuhi kebutuhan psikologis, anggota keluarga ingin diperhatikan, didengar, dan berinteraksi dengan anggota lainnya untuk memenuhi kebutuhan psikologisnya. Jika ini tidak terpenuhi, maka akan melampiaskannya kepada hal-hal negatif yang tidak diharapkan oleh keluarga. Begitu juga dalam komunikasi interpersonal akan mengembangkan kesadaran diri. Anggota keluarga akan sadar diri atau intropeksi diri dan memperbaiki kualitas diri agar diterima oleh anggota keluarga. Fungsi komunikasi ini juga dapat meningkatkan dan menjaga hubungan. Keluarga harus menyisipkan waktu luang untuk selalu bersama dalam komunikasi

\footnotetext{
${ }^{10}$ Enjang A.S dan Encep Dulwahab, Komunikasi Keluarga Perspektif Islam (Cet. I; Bandung: Simbiosa Rekatama Media, 2018), h. 44-62.
} 
interpersonal, sehingga mereka akan semakin akrab, saling menghargai dan dihargai, dan saling menghormati dan dihormati. Selain itu, dengan komunikasi ini, akan dapat menggali informasi tentang anggota keluarga. Dengan komunikasi ini, keluarga akan memperoleh informasi yang akurat dan valid baik tentang pertumbuhan dan perkembangan anaknya dalam hal pendidikan, pergaulan, dan berbagai persoalan yang dihadapinya. Selain itu juga, komunikasi interpersonal dalam keluarga akan berusaha memengaruhi sikap, pilihan, tindakan, tingkah laku, dan keputusan dari anggota keluarga tentang sesuatu.

Keluarga harus menggunakan komunikasi ini dengan baik. Oleh karena itu, ada beberapa sifat yang dimiliki komunikasi ini dan dapat membantu berbagai persoalan internal yang dihadapi oleh keluarga yaitu adanya keterbukaan dan berusaha membuka diri dengan anggota keluarga, perasaan empati, adanya dukungan, adanya perasaan positif, dan adanya kesamaan karena saat bertatap muka akan memunculkan perasaan yang sama antara anggota keluarga. Dengan demikian, para anggota keluarga menggunakan komunikasi secara akrab dan memiliki jarak intim atau jarak dekat dalam berkomunikasi baik verbal dan non-verbal.

Dalam aktivitas keluarga, konflik tidak bisa dihindari. Meskipun keluarga saling menyayangi dan saling mencintai, maka ada suatu kondisi yang bisa menyebabkan adanya konflik. Konflik terjadi karena ada perbedaan kepentingan, tujuan, ego, dan pelanggaran aturan-aturan dalam keluarga. Konflik dapat mengukuhkan hubungan keluarga atau memisahkan hubungan tersebut dan rapuh dan retak. Keluarga yang bisa keluar dari konflik, hubungan keluarga akan semakin kokoh dan kuat. Oleh karena itu, agar tidak terjadi berbagai konflik maka keluarga harus memaksimalkan komunikasi interpersonal dengan meningkatkan kualitas hubungan pribadi baik pada suami-istri maupun pada anak. Selain itu, minimalkan perbedaan kepentingan, tujuan, ego dan pelanggaran yang sudah disepakati bersama.

2. Komunikasi Kelompok dalam Keluarga

Komunikasi kelompok merupakan bagian yang tak terpisahkan dari kehidupan manusia sebagai makhluk sosial. Sebagai makhluk sosial, manusia memiliki keluarga, dan menjadi anggota dari suku atau ras tertentu, serta menjadi bagian yang tak terpisahkan dari masyarakat tempat dimana kita berdomisili, bekerja, memiliki ideologi, dan memiliki hobi yang sama sehingga terhimpun dalam sebuh perkumpulan tertentu. ${ }^{11}$

Komunikasi kelompok dalam keluarga merupakan komunikasi kelompok formal dan informal. Disebut komunikasi kelompok formal karena ada tujuan yang akan dicapai, keuntungan bersama yang akan didapatkan, ada kepala keluarga, ada kepala rumah tangga yang mengatur aktivitas rumah tangga sehinga ada unit kerja dan tim kerja yang bekerjasama untuk mencapai keluarga bahagia dan sejahtera. Selain itu, mereka juga disebut sebagai komunikasi kelompok informal karena lebih mengembangkan tipe keanggotaan secara implisit dan eksplisit dan tujuannya lebih bersifat sosial. Hal lain juga, tidak ada pembagian tugas yang jelas, lebih kepada inisiatif secara sukarela, atau kesadaran akan potensi dirinya yang bisa diberikan pada kelompoknya.

\footnotetext{
${ }^{11}$ Harjani Hefni, Komunikasi Islam (Cet. I; Jakarta: Kencana, 2015), h. 219-220.
} 
Dalam keluarga, komunikasi kelompok dapat berjalan dengan baik jika anggota keluarga saling menghargai, saling memperhatikan, tidak ada pertengkaran dan tidak ada yang merasa lebih berkuasa, posisinya lebih tinggi dan rendah sehingga muncul rasa saling percaya dan amanah. Keluarga harus memunculkan egaliter dalam berkomunikasi, menyelesaikan masalah secara bijak, dari hati ke hati, dan menggunakan komunikasi dua arah atau multi arah. Dengan demikian, keluarga akan bahagia dan harmonis.

\section{Komunikasi dalam Keluarga Perspektif Islam}

Komunikasi merupakan proses pertukaran dan pemaknaan pesan dalam dalam pikiran individu, antarindividu atau kelompok individu melalui interaksi sosial. Interaksi sosial ini dapat terjadi secara face to face atau tatap muka dan non tatap muka. ${ }^{12}$ Komunikasi terjadi dalam keluarga. Komunikasi dalam keluarga adalah proses dialog antaranggota keluarga berupa transfer ide, keinginan atau sekedar perasaan kepada anggota yang lain dalam keluarga, baik berupa perkataan, gerakan petunjuk atau isyarat dan simbol-simbol lain dalam bentuk verbal atau non-verbal yang dapat mengantarkan sebuah keluarga kepada kondisi saling mengerti dan memahami.

Komunikasi dalam keluarga harus dimaksimalkan, karena ia merupakan barometer tercapainya kebahagiaan dan kesengsaraan dalam keluarga. Komunikasi efektif dalam keluarga harus tercapai, karena dengan komunikasi ini, maka hubungan antaranggota keluarga akan semakin akrab, kokoh, dan saling mendukung satu sama lain. Sebaliknya, jika komunikasi ini tidak efektif, maka akan terjadi keretakan dan kehancuran dalam keluarga.

Komunikasi dalam keluarga terdiri atas 3 bagian yaitu komunikasi antara suami dan istri, dan komunikasi antara orangtua dan anak, serta komunikasi antarsaudara. ${ }^{13}$ Untuk lebih jelasnya tentang hal ini, maka penulis akan menjelaskannya secara detail berikut ini :

1. Komunikasi antara suami dan istri

Komunikasi ini dibutuhkan untuk menjaga keutuhan keluarga. Keutuhan keluarga akan tercipta jika dimaksimalkan komunikasi ini. Oleh karena itu, keluarga atau suami-istri harus mengetahui cara yang tepat, efektif dan efisien dalam melakukan komunikasi ini.

Dalam al-Qur'an terdapat contoh komunikasi antara suami dan istri, Q.S. at-Tahrim/66:3-4 :

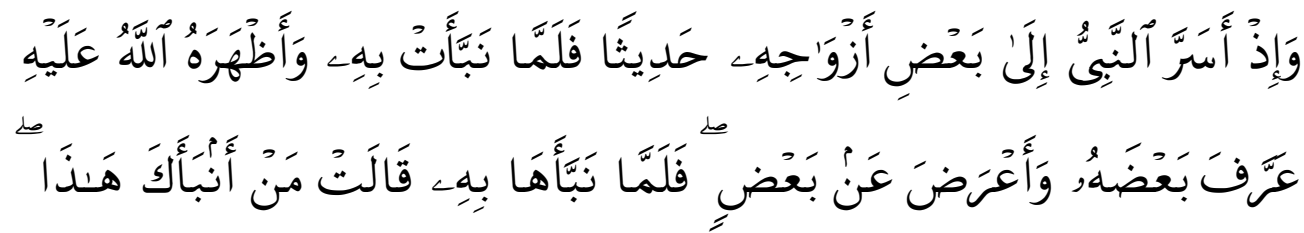

\footnotetext{
${ }^{12}$ Rachmat Kriyantono, Pengantar Lengkap Imu Komunikasi: Filsafat dan Etika Ilmunya serta Perspektif Islam (Cet. I; Jakarta: Prenadamedia Group, 2019), h. 156.

${ }^{13}$ Perpustakaan Nasional RI, Komunikasi dan Informasi: Tafsir Al-Qur'an Tematik (Cet. I; Jakarta: Lajnah Pentashihan Mushaf Al-Qur'an, 2011), h. 348.
} 


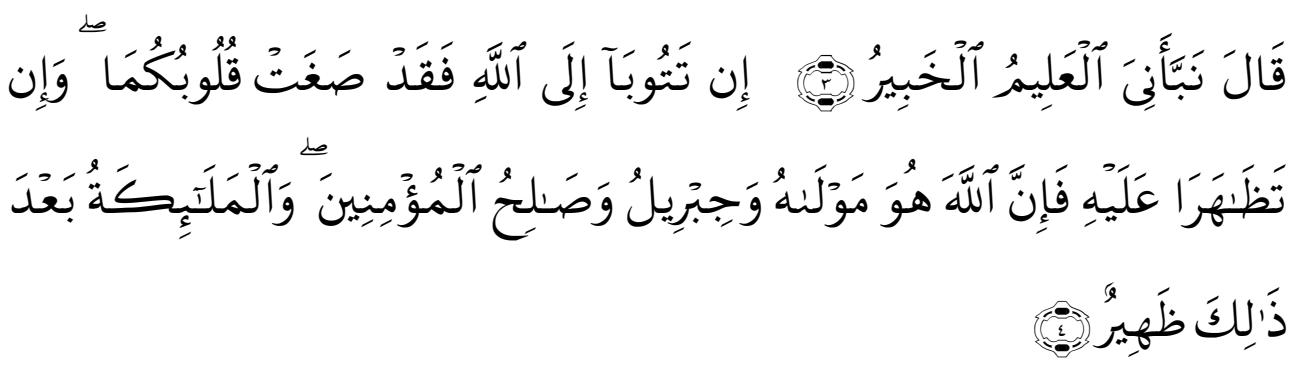

Terjemahnya :

Dan ingatlah ketika Nabi membicarakan secara rahasia kepada salah seorang isterinya (Hafsah) suatu peristiwa. Maka tatkala (Hafsah) menceritakan Peristiwa itu (kepada Aisyah) dan Allah memberitahukan hal itu (pembicaraan Hafsah dan Aisyah) kepada Muhammad lalu Muhammad memberitahukan sebagian (yang diberitakan Allah kepadanya) dan Menyembunyikan sebagian yang lain (kepada Hafsah). Maka tatkala (Muhammad) memberitahukan pembicaraan (antara Hafsah dan Aisyah) lalu (Hafsah) bertanya: "Siapakah yang telah memberitahukan hal ini kepadamu?" Nabi menjawab: "Telah diberitahukan kepadaku oleh Allah yang Maha mengetahui lagi Maha Mengenal." Jika kamu berdua bertaubat kepada Allah, Maka Sesungguhnya hati kamu berdua telah condong (untuk menerima kebaikan); dan jika kamu berdua bantu-membantu menyusahkan Nabi, Maka Sesungguhnya Allah adalah Pelindungnya dan (begitu pula) Jibril dan orang-orang mukmin yang baik; dan selain dari itu malaikatmalaikat adalah penolongnya pula.

Ayat di atas memberikan petunjuk dalam berkomunikasi antara suami dan istri dengan cara selalu meluangkan waktu untuk berkomunikasi, baik dalam mencari solusi terhadap masalah yang dihadapi atau sekedar berbagi cerita, sebagaimana yang dilakukan Rasulullah saw. ketika meluangkan waktunya untuk berdialog dengan Hafsah. Bukan hanya itu, berkomunikasi antara suami dan istri, harus memilih kalimat yang tepat sehingga tidak menyinggung atau memojokkan pasangan. Teguran boleh dilakukan, akan tetapi disampaikan secara halus dan tidak arogan sehingga tidak menyinggung pasangan. Dalam kondisi tertentu, seorang suami dituntut untuk berlaku tegas dalam rangka menjalankan perintah Allah, agar melindungi keluarganya dari api neraka. ${ }^{14}$ Dengan komunikasi antara suami dan istri yang baik, keutuhan keluarga akan semakin kokoh, apapun masalah yang dihadapi akan terpecahkan.

2. Komunikasi antara orangtua dan anak

Keharmonisan keluarga terletak pada hubungan yang baik antara orangtua dengan anak. Komunikasi antara orangtua dan anak memiliki pengaruh yang penting dalam membentuk kepribadian anak. Anak memiliki pribadi yang baik dan jauh dari hal-hal negatif karena komunikasi antara anak dan orangtuanya terjalin dengan baik. Begitu juga sebaliknya. Komunikasi antara anak dengan orangtua dilakukan dengan cara anak

\footnotetext{
${ }^{14}$ Perpustakaan Nasional RI, Komunikasi dan Informasi: Tafsir Al-Qur'an Tematik, h. 353.
} 
berbuat baik kepada orangtuanya dengan kasih sayang, cinta kasih, dan menghormati orangtua.

Dalam al-Qur'an terdapat contoh komunikasi antara orangtua dengan anak, sebagaimana dalam Q.S. As-Saffat/37:102 :

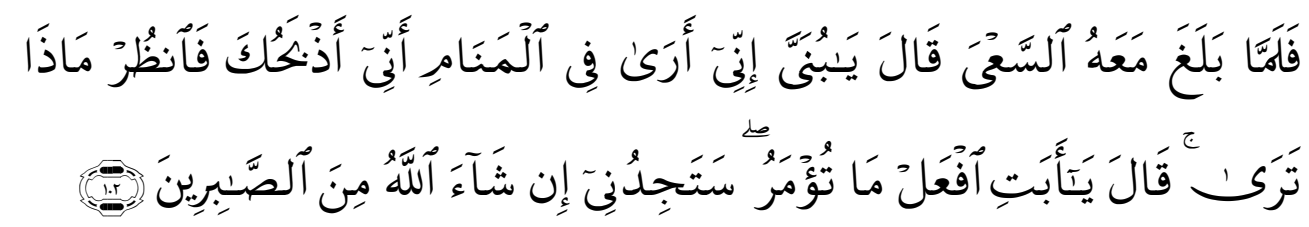

Terjemahnya :

Maka tatkala anak itu sampai (pada umur sanggup) berusaha bersama-sama Ibrahim, Ibrahim berkata: "Hai anakku, sesungguhnya aku melihat dalam mimpi bahwa aku menyembelihmu. Maka pikirkanlah apa pendapatmu!" ia menjawab: "Hai bapakku, kerjakanlah apa yang diperintahkan kepadamu; insya Allah kamu akan mendapatiku termasuk orang-orang yang sabar".

Ayat di atas memberikan petunjuk dalam berkomunikasi antara orangtua dan anak dengan cara menggunakan bahasa yang mengekspresikan kasih sayang, seperti apa yang dilakukan oleh Nabi Ibrahim as., dengan menggunakan kalimat "hai anakku" dengan tidak memanggil nama anaknya. Selain itu, dapat dilakukan dengan cara memberi penjelasan yang detail tentang kejadian atau permasalahan yang ada, sehingga anak mengerti dan memahaminya. Nabi Ibrahim menceritakan dengan jelas apa yang ia lihat dalam mimpinya, sehingga Ismail mengerti kondisi yang sebenarnya. Cara terakhir adalah tidak memaksakan kehendak dan memberi kesempatan kepada anak untuk menyampaikan pendapatnya, sebagaimana yang dilakukan Nabi Ibrahim ketika meminta pendapat anaknya Ismail.

Dengan cara komunikasi seperti di atas, maka kehidupan keluarga akan harmonis tanpa pertentangan dan pertengkaran antara orangtua dan anak, sehingga tercipta keluarga bahagia.

3. Komunikasi antara saudara

Komunikasi antarsaudara tidak kalah pentingnya dengan komunikasi yang lain dalam keluarga. Komunikasi yang baik di antara saudara akan mendukung keutuhan keluarga. Oleh karena itu, dalam Islam sangat mendorong umat manusia untuk selalu menjalin keutuhan keluarga melalui tali silaturahim. Sebagaimana dalam Q.S. an-Nisa/4:1 :

\footnotetext{
${ }^{15}$ Perpustakaan Nasional RI, Komunikasi dan Informasi: Tafsir Al-Qur'an Tematik, h. 365.
} 


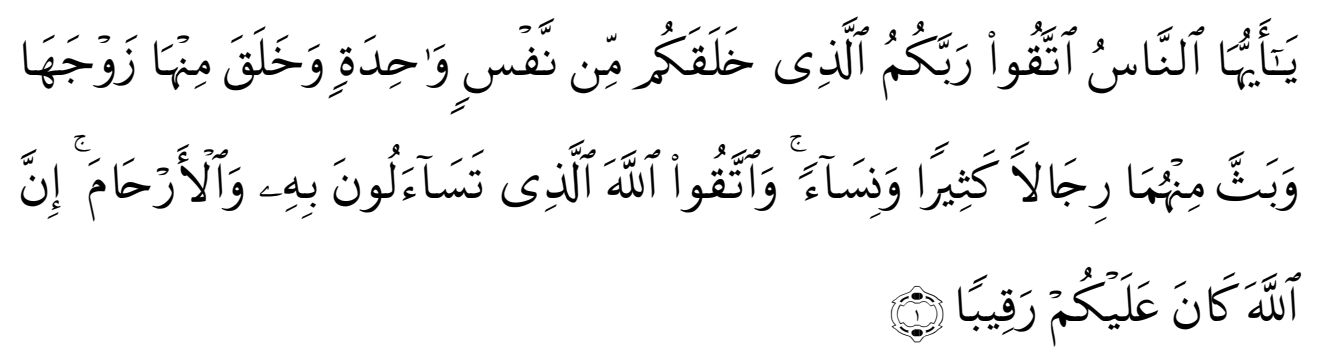

Terjemahnya :

Hai sekalian manusia, bertakwalah kepada Tuhan-mu yang telah menciptakan kamu dari seorang diri, dan dari padanya, Allah menciptakan isterinya; dan dari pada keduanya Allah memperkembang biakkan laki-laki dan perempuan yang banyak. dan bertakwalah kepada Allah yang dengan (mempergunakan) nama-Nya kamu saling meminta satu sama lain, dan (peliharalah) hubungan silaturrahim. Sesungguhnya Allah selalu menjaga dan mengawasi kamu.

Hubungan silaturahim yang dimaksudkan di atas adalah hubungan persaudaraan, baik saudara dekat maupun yang jauh. Salah satu upaya melanggengkan hubungan antarsaudara adalah melalui jalinan interaksi dan komunikasi yang baik.

\section{PENUTUP}

Keluarga dalam al-Qur'an diartikan sebagai kumpulan laki-laki dan perempuan yang diikat oleh tali pernikahan dan di dalamnya terdapat orang yang menjadi tanggungannya, seperti anak dan mertua. Keluarga memiliki peran yang sangat startegis dan fungsi yang sangat bermanfaat. Peran tersebut adalah sebagai pelindung, pendidik anggota keluarganya, penghubung dalam masyarakat, pencukup kebutuhan-kebutuhan ekonominya, pembina kehidupan religius, penyelenggara rekreasi keluarga dan pencipta suasana yang aman dan nyaman bagi seluruh anggota keluarga dan khusus bagi suami-istri, sebagai tempat memenuhi kebutuhan biologisnya. Selain itu, ia juga memiliki fungsi yaitu fungsi edukasi, proteksi, afeksi, sosialisasi, reproduksi, religi, ekonomi, rekreasi, biologis, dan transformasi. Agar peran dan fungsi ini berjalan dengan baik, maka dibutuhkan komunikasi yang efektif dalam keluarga. Komunikasi yang terjadi dalam keluarga bisa berbentuk komunikasi interpersonal dan bisa juga berbentuk komunikasi kelompok.

Dalam Islam, al-Qur'an secara umum telah menjelaskan tentang komunikasi dalam keluarga. Komunikasi ini dapat dibagi menjadi tiga bagian yaitu komunikasi antara suami dan istri, dan komunikasi antara orangtua dan anak, serta komunikasi antarsaudara. Ketiga komunikasi ini jika berjalan efektif, maka keutuhan, keharmonisan dan kebahagiaan keluarga akan tercapai. 


\section{DAFTAR PUSTAKA}

Al-Baqy, Muhammad Fuad. al-Mu'jam al-Mufahras li Alfazh al-Qur'an al-Karim. Beirut: Dar al-Fikr, 1987.

Enjang A.S dan Encep Dulwahab. Komunikasi Keluarga Perspektif Islam. Cet. I; Bandung: Simbiosa Rekatama Media, 2018.

Hefni, Harjani. Komunikasi Islam. Cet. I; Jakarta: Kencana, 2015.

Kriyantono, Rachmat. Pengantar Lengkap lmu Komunikasi: Filsafat dan Etika Ilmunya serta Perspektif Islam. Cet. I; Jakarta: Prenadamedia Group, 2019.

Ma'arif, Bambang S. Komunikasi Dakwah : Paradigma Untuk Aksi. Cet. I; Bandung: Simbiosa Rekatama Media, 2010.

Ngalimun. Ilmu Komunikasi : Sebuah Pengantar Praktis. Cet. I; Yogyakarta: Pustaka Baru Press, 2017.

Perpustakaan Nasional RI. Komunikasi dan Informasi: Tafsir Al-Qur'an Tematik. Cet. I; Jakarta: Lajnah Pentashihan Mushaf Al-Qur'an, 2011.

Soelaeman, Moehammad Isa. Pendidikan dalam Keluarga, Bandung: Alfabeta, 1994.

Solikin, Nur. Rumahku Madrasahku: Jadikan Rumah sebagai Pusat Inspirasi Anak. Cet. I; Yogyakarta: Laksana, 2018.

Undang-Undang No. 23 Tahun 2002 tentang Perlindungan Anak, Bab I Pasal 1, Jakarta: Indonesia Legal Center Publishing, 2003. 